\title{
Christians in the Nineveh Plains: Focusing on Possible Self-Governance for Minorities
}

\section{Zaianddin Mawlood Khidhir}

Department of International Relations Actual classification, Institute of International, Political and Regional Studies, Corvinus University of Budapest, Budapest, Hungary.

E-mail: zainaddin.mawlood@uor.edu.krd

\section{Rostovanyi Zsolt}

Department of International Relations Actual classification, Institute of International, Political and Regional Studies, Corvinus University of Budapest, Budapest, Hungary.

E-mail: rostovan@uni-corvinus.hu

\section{Zubir Rasul Ahmed}

Department of international relations, College of political science, Salahaddin University, Erbil, Kurdistan, Iraq. E-mail: zubir.ahmed@su.edu.krd

\begin{abstract}
:
A deeply complicated situation characterizes Mesopotamia and its neighborhood, with a lasting solution to the fate of minorities in the region yet to be comprehended. In this secondary study, the central purpose is to investigate issues and the fate of Christians in the Nineveh Plains, ranging from their dream for self-governance to the displaced nightmare. Particularly, the study seeks to gain insight into prospects of self-governance for minorities, shedding light on some of the platforms that the affected communities could exploit to realize this dream, as well as major hurdles that they might encounter. The study's specific objectives include the examination of the current degree of success in Iraqi minorities' quest for self-governance, some of the challenges facing the community, and some of the feasible solutions that are worth embracing. From the findings, some of the challenges facing the Iraqi minorities' quest for self-governance is seen to include the militia harassment and land seizures against minorities, translating into irritation. Therefore, self-governance and self-determination are the key factors that would necessitate chances of the Iraqi minorities' survival, but the reconciliation process requires interventions by international organizations such as United Nations.
\end{abstract}

Keywords: Christians, Nineveh Plains, Self-Governance, Minorities. 


\section{Background of the study}

Despite the successful retaking of Iraq from the Islamic State (ISIS), minorities are diminishing continuously, having experienced human rights abuses disproportionately. Even before the fall of Mosul, these groups continued to fear for their future amidst the absence of clear security measures through which returns could be encouraged, the region rebuilt, and the communities protected, a situation worsened by competing land claims (Ali, 2017). In a region such as the Nineveh Plains, the fate of Christianity continues to exhibit geopolitical significance. For healthy and liberal democracies, research suggests that their features lie in the protection of minorities, as well as the ability to provide room for these groups to engage in societal affairs freely (Ali, 2019). The implication is that the existence of religious minorities in a region plays a crucial role whereby it tests the degree to which a country could tolerate pluralism (Cetorelli and Ashraph, 2019). In Muslim-majority zones, the extent to which Christians could thrive and survive reflects the presence or absence of viable democracy in those areas (Ali, 2019). Currently, a grim outlook characterizes Iraq, a similar trend that continues to be witnessed in other nations with historic Christian populations - such as Turkey, Syria, and Egypt (Crone, 2015). In these places, many scholarly investigations avow that Christians have continually faced routine violence, government-sanctioned intimidation, and discrimination (Dewachi, 2017).

However, the U.S. government has emerged as a powerful and influential previously that has provided notable support to Christians in the Middle East, a decision that dominates American foreign policy. Particularly, significant investment has been extended to the Nineveh Plains (Dietrich and Carter, 2017). Despite these efforts and also the provision of room for Christians wishing to remain in their home countries to do so, the Nineveh Plains has seen an increasing number of families remain ambivalent relative to their future in the region. The eventuality is that there is support from Washington, but Christians in the Nineveh Plains remain vulnerable. Also, it is evident that the decision on whether the families will opt for or against staying in the region will determine the survival of Christianity in an otherwise area where it first gained root. 


\section{Problem Statement of the study}

In Iraq, minorities have experienced war since the creation of Iraqi state in 1920. Due to the devastating nature of this adversity, an increasing number of these communities remain on the verge of disappearance (Donabed, 2015). Not only have millions fled, but tens of thousands of members of minority groups have been killed (Gardner, 2016). Before 2003, the Christian population in the Iraqi context was about 1.4 million. However, by 2016, the population was estimated to be less than 250,000 (Helfont, 2018). After a U.S.-led coalition toppled Saddam Hussein, the country has continually been engulfed by sectarian tensions and civil conflicts. The year 2014 also saw militants belonging to the Islamic State (ISIS) declare a caliphate, having captured Syrian and Iraqi swathes (Hanish, 2015).

Some of the notable minorities that have been affected disproportionately include Kaka'i, Christians, Shabak, Turkmen, and Yazidi (Helfont, 2018). In the ancient Mesopotamia, one of the indigenous groups, Yazidis, has been affected adversely whereby most of the followers of Yazidism have been persecuted and killed because of accusations of "devil" worshipping, having predated the Abrahamic religions (Ibrahim, 2018). Whereas the population of this indigenous group was about 700,000 by 2005 (Johnston, Alami and Clarke et al., 2019), recent demographic statistics suggest that it has been reduced to about 500,000 people in Mesopotamia (Kaya, 2019). In Iraq's post-ISIS era, many Yazidis have been enslaved or displaced. For instance, about 6,800 Yazidis were kidnapped to be used as fighters or sex slaves, while 3,100 were killed around Mount Sinjar (Millare, 2019).

In Mesopotamia, the Iraqi Turkmen (who constitute the third-largest minority community) have also been subjected to displacement. Whereas many of these members are Sunni or Shi'a Muslims, a small minority documented to be about 30,000 are Christians. In a quest to provide room for Arab communities, many Iraqi Turkmen have been displaced, with ISIS killing and also subjecting most of the women to sexual abuse. Indeed, Tal Afar has been one of the worsthit districts in the neighborhood (Mosul Study Group, 2017).

Indeed, it is evident that the repercussions of the havoc caused by ISIS, the ensuing security vacuum, and the Iraqi civil war have seen minorities in Mesopotamia issues ranging from arbitrary punishments, abductions, gross human rights abuses, and civilian casualties to the destruction of cultural heritage, displacement, and the use of chemical weapons (O’Driscoll, 2017). In particular, recent observations suggest that over two million people belonging to the minorities have been displaced in the area and its neighborhood. The situation seems to have been worsened by the beginning of the Mosul offensives that saw over 441,000 individuals uprooted from their homes in May 2016 alone. Of these, only 105,000 have been reported to return (Oehring, 2017). It is also imperative to highlight that in some of these operations, ISIS deployed chlorine gas. The uprooting and hundreds of abductions have, therefore, led to the brainwashing of most 
of the young boys with ISIS propaganda while many women have been forced into sex slavery for ISIS members (Robinson, Egel and Johnston et al., 2017). Thus, a deeply complex situation characterizes Mesopotamia and its neighborhood, with a lasting solution to the fate of minorities in the region yet to be comprehended.

\section{Objectives of the Study}

With interest in and the presence of powerful players in this area, how Christians will constantly work and ensure that they succeed in navigating the complicated network of political and sectarian interests remains an inconclusive debate. In this study, the central purpose is to investigate issues and the fate of Christians in the Nineveh Plains, ranging from their dream for self-governance to the displaced nightmare. Particularly, the study seeks to gain insight into prospects of self-governance for minorities, shedding light on some of the platforms that the affected communities could exploit to realize this dream, as well as major hurdles that they might encounter. The study's specific objectives are stated as follows:

- To determine the current degree of success in Iraqi minorities' quest for self-governance

- To find out some of the challenges facing Iraqi minorities as they seek to achieve self-governance in the Nineveh Plains

- To recommend feasible solutions through which Iraqi minorities might address challenges facing their quest for self-governance in the Nineveh Plains

\section{Questions of the study}

In this study, the central research question is what are the issues and the fate of Christians in the Nineveh Plains regarding their dream for self-governance? Other research questions aimed at achieving the study's specific objectives are stated as follows:

* What is the current degree of success in the Iraqi minorities' quest for self-governance?

What are some of the challenges facing the Iraqi minorities as they seek to achieve self-governance in the Nineveh Plains?

* What are some of the feasible solutions through which the Iraqi minorities might address challenges facing their quest for self-governance in the Nineveh Plains? 


\section{Review of Literature about Minorities Self-Governance in Iraq}

Iraq's interim constitution, which has been acknowledged by some scholars as being impressively liberal (Rubaii, 2019), was produced at a time when the country was under great pressure of time (Salloum, 2017). Some of the major constitutional principles governing the guideline include extensive minority vetoes and federalism. The Constitution was adopted on 15 October 2005, coming in the wake of a highly disputed referendum (Shea, 2016). In Article 2, the Constitution states that all individuals (including minorities such as Mandean Sabeans, Yazidis, and Christians have full religious rights and freedom of religious belief and practice. Also, Article three acknowledges explicitly that Iraq is a country of multiple sects, religions, and nationalities (UNHCR, 2019). In Article 4(1), the constitution guarantees Iraqis the right to ensure that their children are educated in mother tongue in government educational settings, including minorities such as Armenian, Syriac, and Turkmen (Wainscot, 2019). Hence, the Constitution promises minorities the right to mother tongue education. It is also notable that discrimination is prohibited, as specified in Article 4. Particularly, the Constitution states that before the law, Iraqis are equal and that discrimination against persons based on social or economic status, opinion or belief, sect, religion, colour, origin, nationality, ethnicity, race, or gender is prohibited (Zaman, 2016). In Chapter 4 of Article 125, the Constitution guarantees educational, cultural, political, and administrative rights to members of various nationalities, minorities such as Assyrians, Chaldeans, and Turkmen included (Ali, 2017). Overall, the 2005 Constitution of Iraq is seen to strive to build on the 1932 Declaration and provides several rights to minorities, with the theme of equality dominating provisions in the legal framework. A subject that becomes important to investigate and unearth is the degree to which the Constitution has aided in responding to and addressing minorities' problems since 2003, especially in the wake of growing disasters that continue to befall Iraq.

Whereas the majority of international groups have focused their attention on the conflict between Arabs and Kurds, especially in Kirkuk, an oil-rich city that houses disputed authorities, Nineveh forms a leading battlefront in the conflict (Ali, 2019). In particular, Nineveh, based on recent statistics, is the second-most populous province in Iraq. Also, the province hosts historical minority groups in unique concentration (Cetorelli and Ashraph, 2019). On the one hand, the Constitution specifies that Nineveh is under the country's central government's jurisdiction. On the other hand, sometimes even governmental authorities are out to reshape the province's reality, especially since the Oct. 16 events, the governor of Kirkuk brought thousands of Arabs to the Dibis and Sargaran areas," (Quoted in Goran, 2018). This can be very dangerous on the coexistence of minorities in post 2003 Iraq.

Therefore, most of the minorities have lost their original lands. For example, 2008 events in Mosul, which involved orchestrated and systematic campaigns of violence and targeted killings, witnessed over 12,000 Chaldo-Assyrians displaced, with about 40 killed (Dietrich and Carter, 2017). Also, there the month of August 2007 saw Nineveh's 
simultaneous truck bombings account for over 300 Yazidi deaths, with over 700 wounded and displaced in one of the worst single attacks targeting civilians (Donabed, 2015). At a time when there is a growing debate of whether or not to establish a province for Christians and other minorities in the Nineveh Plains as a safe haven, wishes of the majority of the inhabitants are lost. Particularly, most of the inhabitants have been displaced forcibly.

For instance, recent surveys by the Nineveh Center for Research and Development suggest that more than 4,000 Christians and Yazidis were displaced in 2014, with Syriacs and Chaldeans dominating the Christian group (Gardner, 2016). Additional research suggests that whereas some of the minority community members who have been displaced would wish to return (five percent), a significant proportion (42 percent) prefer leaving Iraq and securing safe havens abroad (Hanish, 2015). For the majority of those who are against returning, the dominant reason cited involves neighbours' betrayal via collaboration with ISIL (Helfont, 2018).

Militia armed groups is also seen to account for minorities' displacement by claiming to their territories. The militia groups have been accused of persecuting Assyrian Christians, as well as evicting most of them from their homes forcefully while citing to be fighting ISIL. As asserted by sections of Yazidi Human Rights Organization International representatives, Yazidis have also been affected adversely whereas these armed groups has ended up exploiting their vulnerability and suffering at the expense of defeating ISIL (Johnston, Alami and Clarke et al., 2019).

Overall, the observations above suggest that most of the minorities in the disputed territories of the Nineveh Plains have lost their land and operated under the control of Iraqi government as refugees. The situation might be compounded further by the pressure that the Iraqi government continues to put on the refugees to sign the Declaration of Allegiance, whose validation of the other ethnic groups "return" of the Nineveh Plains to other cities might mark the minorities' permanent loss of their original land.

Annihilation refers to a state of total defeat or destruction of an individual, a community, or a system. In the Iraqi context and the equation of the inconclusive debate concerning the fate of minorities in the Nineveh Plains, the subject of possible annihilation implies discussions about possible extinction or total destruction. In particular, the emerging question is, are minority communities in this disputed terror under the danger of extinction?

In the Nineveh Plains, discriminatory laws, lack of opportunities, and insufficient security continue to deprive minority community members (Kaya, 2019). These members neither enjoy fundamental rights that could guarantee their existence nor receive adequate protection by the post -2003 Iraqi governments (Millare, 2019). For these minorities, life has been turned to a nearly impossible mission, coming at a time of pervasive rejection of their religious and ethnic 
elements, as well as persistent violence. Since 2003 therefore, in response to these problems, a huge exodus has occurred, a trend marking the greatest threat to the minorities' survival in the disputed territory.

In about 17 years, over 50 percent of the Assyrians have left the region. In regions such as Syria, Jordan, and other parts of the world, Iraqi refugees (mostly from the disputed territory) are about two million, yet 30 percent of these are minorities (Mosul Study Group, 2017). According to O'Driscoll (2017), adversities such as growing religious intolerance, difficulties in education, financial hardship, and unemployment characterize most of the minorities' daily life, especially Assyrian Christians. Oehring (2017) observed further that subjection to a pattern of neglect, marginalization, and official discrimination has made most of the minority community members to perceive that they are no longer tied to or part of the Nineveh Plains, treating themselves as persons excluded from civil society.

Notably, most of the inhabitants of the Nineveh Plains are indigenous minorities, yet problems such as underdeveloped structures, corruption, political mismanagement, and unemployment threaten their existence. Robinson, Egel and Johnston et al. (2017) stated that with desperation setting in, most families have remained restless, moved from place to place, and endlessly expressed the desire to leave the region. Focusing on the current situation in Iraq and whether or not minorities are on the edge of annihilation, a study by Rubaii (2019) revealed that most of the affected community members liken a disputed region such as the Nineveh Plains to a graveyard for religious and ethnic minorities, findings that were similar to those reported by Salloum (2017), who noted that most of the inhabitants perceive issues in the region as the occurrence of another Holocaust. With the minorities unsure, delicate, and precarious, a question that is worth examining is whether decades of strive might permanently render them invisible in the immediate future.

In response to the question of whether minorities, especially those inhabiting the Nineveh Plains, are on the edge of extinction could be better approached based on the shift in demographics of the specific groups that have been targeted, especially by ISIS and other militants. For Christians, livelihoods and homes have been destroyed, with ISIS attempting to ensure that across the territory and the rest of Iraq, any memory about Christianity is destroyed completely. Whereas country estimates suggest that Christians have reduced from 1.5 million (before 2003) to about 150,000 to 200,000 in Iraq, the situation in Nineveh seems direr. In this area, Shea (2016) observed that only about 40,000 Christians displaced internally have returned to the territory, their ancient homeland. Even for this group that has returned, problems of violence, intimidation, and discrimination are prevalent, with Iran's backing of the militias making their hopes of cling onto their property and land fade (UNHCR, 2019).

In Sinjar province, Yazidis have been worst hit. With ethnic cleansing that ISIS launched, recent statistics indicate that about 2,900 Yazidis are yet to be traced, with over 400,000 living in displacement (Wainscot, 2019). Also, 68 heritage 
and religious sites have been destroyed, with 70 mass graves yet to be exhumed. Indeed, these sample statistic analyses suggest a high rate of population decline among minorities in the Nineveh Plains and other parts of Iraq. In relation to the question of potential annihilation, the outcome will depend on how the militias and the anti-militia groups will succeed in their agenda. Should the recurring cycle of violence persist, the minorities' extinction in the Nineveh Plains, a disputed territory, is possible. However, if strategies such as establishing a province for minorities as a save heaven are implemented successfully, the population of the affected communities might be restored gradually.

In Iraqi Kurdistan, the government and people have played a leading role in ensuring that all religious minorities, Yazidis, and Christians are protected. Whether non-Muslim or Muslim, people have gained freedom in such a way that the practice of their religion has remained open (Zaman, 2016). With ISIS taking control of a vast region in the northern part of the country in 2014, KRG has proved to be a safe haven for providing assistance and vital security. Statistically, the safe haven has attended to about two million Iraqis displaced internally, with Yazidis and Christians dominating this population (Ali, 2017). In the Kurdistan region, 20 percent of the people are either internally displaced persons (IDPs) or refugees. Also, the most affected province is Dohuk, where some villages have seen the ratio between IDPs and locals stand at 1:1 (Ali, 2019). With billions of dollars spent on addressing the IDPs' needs, some of the services that KRG has provided include camp monitoring, camp management, education, security and protection, electricity, water, and health services (Cetorelli and Ashraph, 2019).

Before an ISIS offensive attack, Mosul's Christian population was around 10,000. However, most of these families fled and sought refuge in Kurdistan to be protected by the local Peshmerga army - from hard-liner Sunni fighters (Crone, 2015). Indeed, Kurdistan, has proved unique from the rest of the Iraqi zones whereby it has preserved coexistence among diverse communities successfully. For oppressed minorities, therefore, the region reflects a safe haven and a "new heaven." However, it is worth noting that in the wake of northern Iraq's previous power vacuum, the Peshmerga took advantage and ended up extending their influence outside Kurdistan's borders (Dewachi, 2017). Whether this extension of the influence might compromise the successful assurance of community co-existence in the region remains debatable.

Indeed, Kurdish forces have protected refugees in Bashiqa town, whose distance of separation from Mosul stands at about ten kilometers. Despite this promising trend in Kurdistan, several issues pose a dilemma in relation to the existence of refugees of minority communities in the region and whether or not efforts should be made in the post-ISIS era to return them to their ancestral lands. Specifically, one of the issues is how the military, economic, and political assets could be mobilized to ensure that on the Nineveh Plains, a multi-ethnic province is established. Another issue that is yet to receive in-depth analysis is whether and how a contiguous safe haven could be created, encompassing the 
Nineveh Plains, Tal Afar, and Sinjar. Should this project be successful, it remains inferable that there might be a significant transition to realize a self-administered province or various provinces in Iraq.

However, prospects of such efforts come at a time when there are also mixed opinions among the minorities themselves, with some arguing in favor of staying while others are keen to emigrate. Of importance to note is that Kurdistan has, indeed, played a crucial role and even ensured that the U.S. foreign policy regarding the criticality of this safe haven in fulfilling its (United States') operational needs of fighting ISIS is achieved. With the U.S. strategy concretized and strengthened, whether the stability might spread to the rest of Iraq or remain or only be felt in Kurdistan remains unknown. Overall, it is worth acknowledging that Kurdistan has transitioned from a killing zone to a safe haven for minorities and that its existence as a destination for most of the refugees and IDPs has fulfilled three specific interests of the U.S. these interests include territorial interests (in which ISIS and its offshoots have been weakened and also promised to protect disputed lands during post-ISIS), political interests (in which minorities might enjoy greater political participation after strengthening cohesiveness and diversifying the region's political landscape), and geopolitical interests (in which expansionist foreign powers have been blocked and also demonstrated that good governance and coexistence is possible).

As highlighted above, the Kurdistan Region of Iraq (KRI) has played a crucial of achieving diversity and co-existence among communities, a trend that has seen the region house most of the minorities fleeing religious persecutions. However, the "new heaven" has not gone without direct challenges with which the minorities have had to grapple. When Mosul was seized by ISIS, hundreds of thousands of individuals of different ethnicities fled to KRI to secure shelter in a mix of parks, schools, mosques, and hotels (Dietrich and Carter, 2017). With a significant increase in population, checkpoints have had to be closed regularly, keeping thousands of individuals waiting for periods as long as five days, a problem exacerbated by lack of adequate communication and also water, food, and shelter (Donabed, 2015). Similarly, access rules have been reported to be applied differently based on the religion and ethnicity of the affected persons. For instance, Gardner (2016) observed that for Christians, Kurds, or individuals with sponsors within Kurdistan, they are likely to pass easily while most of the Turkomen, Shia Arabs, and Sunni have been sent to temporary holding sites. At checkpoints, access points have also been observed to be unpredictable (Hanish, 2015).

For researchers who have focused on the humanitarian situation in the KRI, the region's absorption capacity has also been questioned, with displaced populations coming in high numbers - at a time when the KRI is also experiencing limited and decreasing humanitarian aid, increasing poverty, and deteriorations in socio-economic conditions (Helfont, 2018). Some of the specific problems arising from a large number of displaced persons in KRI's urban zones include a significant decline in the standards of living, increased job competition, and strained local services and infrastructure 
(Ibrahim, 2018). Similarly, most of the IDPs in informal settlements (such as abandoned or unfinished buildings) and camps have experienced extreme weather conditions, as well as poor sanitation infrastructure and inadequate water (Johnston, Alami and Clarke et al., 2019).From an employment perspective, many of these IDPs can only secure casual work, implying that the majority do not have a regular income (Kaya, 2019). Other areas where problems have persisted include education and health care (Millare, 2019). Even in the wake of post-ISIS, many minorities such as Yazidis have not managed to return to areas such as Sinjar District due to various problems within and outside KRI. Some of these issues include safety concerns, lack of financial means to return, fear of discrimination, the damaging or destruction of their houses in the Nineveh Plains, and presence of mines (Mosul Study Group, 2017). Others include persisting community tensions and lack of basic services and livelihoods (O’Driscoll, 2017).

\section{Findings and Analysis}

From Article 125, the Iraqi Constitution guarantees educational, cultural, political, and administrative rights of different nationalities, including Assyrians, Chaldeans, Turkomen, and other constituents (Oehring, 2017).Based on this provision, Robinson, Egel and Johnston et al. (2017) stated that the aim is to ensure that a truly pluralistic and democratic Iraq is realised, especially due to the need to provide room for minorities to remain Iraqi society's productive elements, as well as live securely in a region such as the Nineveh Plains. However, a debate that is yet to be analyzed comprehensively is whether external parties such as the U.S. and other decision-makers in the West should acknowledge the criticality of intervening to ensure that for Iraq's persecuted minorities, protection and political space are provided and that they gain an opportunity to advance the agenda behind Article 125 of the Constitution. For Syriac, Chaldean, and Assyrian Christians, the policy or legal framework promises them survival. With the dilemma of if and how the U.S. and its allies should intervene or collaborate with Iraqi government to implement the stated Article yet to be solved, minorities remain victims of wide-scale ethnoreligious cleansing, yet there is urgency for Iraq to be transformed into a fully federal state, a state of stabilization that depends on how far Article 125 will be enacted.

For studies that have focused on the possibility of minorities succeeding in achieving the goal of Article 125, a key subject has been whether and how a separate administrative region could be created while ensuring that the process abides by the Article's provisions (Rubaii, 2019). From a federal perspective, debates about autonomy are complex in Iraq (Salloum, 2017). Firstly, "autonomy" could be seen to reflect aspects such as secessionism, devolution, or decentralization. On the other hand, federalism could be seen to partition the country, a trend that Shea (2016) cautioned that it could translate into violence and regional instability. For minorities, entering a federalism dialogue to implement Article 125 to the latter also comes with challenges, especially regarding the credible threat of force, as well as lack of power. To achieve their constitutional rights, therefore, minorities might have to rely on the respect for and the 
development of the rule of law, which has proved difficult to achieve due to ever-growing ethnic tensions even during the post-ISIS era.

With minorities seen to be limited by the aforementioned issues, another question that remains debatable is whether there should be international intervention to ensure that through Article 125's implementation in Iraq, they (minorities) realise their constitutional rights. Recently, the U.S. invested in religious and ethnic minority assistance in Iraq and targeted the area of political, economic, and social empowerment. In particular, 8.5 million dollars have been provided to assist with legal support and offer psychological services, as well as support initiatives through which evidence about abuses of human rights might be collected. Also, the funding has aimed to provide access to economic opportunities for minorities, offering livelihoods support, strengthening the rule of law, increasing access to justice for children, and increasing minority representation in provincial and local government (UNHCR, 2019). Whereas Wainscot (2019) documented that these efforts reflect a promising step via international intervention, Zaman (2016) cautioned that they are reactive and that Article 125's full implementation might be felt only if minorities, especially in the Nineveh Plains, will be empowered and well placed to handle the aforementioned initiatives with little or no international intervention. Hence, the mixed outcomes demonstrate that there is international intervention, but an ideal situation that might see minorities fully enjoy their rights as guaranteed by Article 125 of the Iraqi Constitution is that in which the initiatives mentioned above will have the implementing groups dominated by representatives from the affected minority communities, rather than international persons and organizations.

With the evidence of a conflict zone in Iraq, especially in the Nineveh Plains where minorities mostly constituting Christians are the worst-hit, the question is what next? And what is the fate in the immediate and far future, with Mosul having been regained?

Of importance to note is that at a time when the grip of ISIS on Ninewa, Kirkuk, Salah al-Din, and Diyala governorates is weakening, it becomes important for a clearer way forward to be developed. In this study, it is acknowledged that during post-ISIS planning, a concrete, practical, and lasting solution will be released only if it includes collaboration building among four major parties with support of the Iraqi government, KRG, minorities and international community, would be needed. . These parties include minority communities, the international community, the KRG, and the Iraqi government. Also, the mixed outcomes that this study has established regarding the complex and delicate situation in Iraq leads to the inference that an ideal solution is that which will focus on pressing concerns that include a long-term reconciliation, economic, and administrative framework seeking to protect minorities, return issues, missing persons, property rights, and security. 


\section{On Self-Governance}

Following ISIS' running of a campaign of genocide, which targeted the Nineveh Plains' minorities, most of the affected sections such as Yazidis and Christians have renewed calls for autonomy. Alongside Turkmen and other leaders across Iraqi, the groups have advocated for the creation of a zone for minorities, exclusively, in the north, with three provinces on the focus. Indeed, this path could be promising because the resultant self-governance might preserve the existence of an otherwise endangered minority population in Iraq. Also, this step could aid in compensating for the minorities' loss of belongings, wealth, and land. However, mixed outcomes accrue regarding these prospects of self-governance, the degree of success so far, and some of the challenges that continue to face the minorities' quest for autonomy.

One of the renowned persons who have contributed to this debate is Nicodemus Daoud Sharaf, the Syriac Orthodox Archbishop of Mosul. In his view, Christians ought to live in areas where law prevails, a stance that is seen to lean towards the need for self-governance. In support of this view, Rubaii (2019) acknowledged that given the significant decrease in the number of Christians, regardless of a relatively stable number as observed in Erbil and Kirkuk, the provision of room for the minorities to create their stability forms a promising path towards ensuring that their existence in Iraq is preserved.

In affirmation, Salloum (2017) asserted that for Yazidis, Christians and other minorities, the solution neither lies in staying and suffering nor emigrating to the West. Rather, their lasting presence could be preserved only if a province is established in Sinjar for Yazidis, and a province created in the Nineveh Plains for Christians. Notably, successful implementation of these strategies can be seen to aid in stemming the emigration of minorities out of Iraq, especially if the Nineveh Plains province follows the repurposing of the districts of Shekhan, al-Shikhan, al-Hamdaniyah, and Tel Keif. Shea (2016) contended that this is a promising step because it seeks to ensure that local communities are empowered. For this trend as one of the ways reflecting prospects of self-governance for Iraqi minorities, it is worth concurring that it is a promising step because it comes at a time when there are efforts to ensure that across the country, power is decentralized, having liberated Mosul. Thus, implementing this path reflects a timely step, coming in the wake of enabling conditions. Another factor that is seen to provide room for a conducive and supporting environment (and also points to the timeliness of the idea of self-governance) involves diverse identities and opinions characterizing Iraqi minorities, influenced by linguistic, ethnic, local, and national factors. Therefore, creating a minority-haven province as a path towards self-governance would imply further that these differences are likely to be celebrated.

Of importance to note is that even at a time when there is growing interest in self-governance for Iraqi minorities, one of the notable challenges facing this quest involves the inconclusive debate of whether the self-governance idea should 
be implemented in a manner that would see Iraqi minorities operate as part of Kurdistan. The complexity of the debate is drawn from events in other parts of the world. As avowed by Wainscot (2019), decentralized and federal governance models have proved to be successful solutions in post-conflict reconstruction, especially in regions such as Syria, Yemen, and Libya. Also, self-governance has been avowed to be a lasting solution because it guards against sects that seek to overreach their rule (Zaman, 2016).

However, the inconclusive subject of whether or not the Nineveh Plains should operate under Kurdistan arises from a recent situation in which the Peshmerga announced that following Mosul's liberation, it would not withdraw from the area (the Nineveh Plains). Due to this stance, the possibility at the minorities' disposal is that in which Nineveh Plains as a semi-autonomous province will have to fall under the KRG control. However, the positive side is that with relative stability and prosperity have been realized via decentralization in Kurdistan, Iraqi minorities' quest for self-governance might be backed by pro-decentralization Kurds, who might advocate for a Christian-Yazidi province falling under the control of KRG. Given the rich oil reserves in the Nineveh Plains, the KRG might support the decentralization, but minorities' operation under or as part of Kurdistan implies that self-governance would not have been achieved fully.

Based on the analysis above, some of the challenges facing Iraqi minorities' especially from militia armed groups and the future relations of the KRG with these minorities. Despite these mixed outcomes, a positive path reflecting a growing interest in and pressure towards a regional government approval is seen to be reflected by the KRG's extension of positive treatment to Yazidis and Christians. It is also notable that the KRG has offered stability and that the KRG versus minorities' issues are relatively minor compared to the friction that Yazidis and Christians have had with other powers in the region, a path that points to a possibility of semi-autonomy for minorities, but operate under Kurdistan.

Another hurdle is that currently, the law in Iraq provides room for provinces to unite under Kurdistan as a region but does not offer a legal pathway through which districts could unite and form provinces. The implication for the effort towards self-governance is that to create provinces, the Nineveh Province's many districts, based on the Iraqi would, would have to devolve and form smaller provinces before allowing for the provinces to create an autonomous region of self-governance. As affirmed by Rubaii (2019), further complexity arises in such a way that should a province be created, many minorities might become targets by their neighbors in the future. However, the positive side is that upon creating a province, there might be an easier expedition of the aid process, allowing Yazidi community organizations or church organizations to provide aid to people directly. Should security be guaranteed, Salloum (2017) asserted that another beneficial effect of self-governance would be that Diaspora might return and invest or establish businesses in the province, a necessary step that needs to precede the people's return to their villages. Overall, this chapter infers that 
self-governance and self-determination are the key factors that would necessitate chances of Iraqi minorities' survival, but the reconciliation process requires interventions by international organizations such as those in the West, with the United States Institute of Peace (USIP) unexceptional.

\section{Recommendations:}

To alleviate the humanitarian catastrophe in Iraq, Iraq's federal government should emerge as a primary and responsible player and ensure that displaced Iraqis are supported through the establishment and implementation of a comprehensive strategy for addressing the humanitarian emergency. Through international support and state funding, the government should ensure adequate resource availability. Also, the government needs to allow for the issuance of credentials and identity documents on an emergency basis, especially among IDPs in different governorates, upon which the affected minorities will be better placed to access government or basic services and rations. Similarly, the federal government needs to develop a registry of missing persons to ensure that missing person claims are registered, a task that should be delegated to the Ministry of Human Rights. Regarding the delivery and procurement of humanitarian aid, the federal government needs to initiate impartial, independent, and prompt investigation into corruption and ensure that any responsible persons are prosecuted. For victims, specialized services such as psychological counselling need to be provided, especially women and young girls who have been victims of sexual violence, as well as traumatized children.

In the post-ISIS era, there is a need for immediate planning to develop secure areas, enabling minorities to return to their lands and homes. To achieve this objective, the federal government should seek international support, especially due to the need for an otherwise costly process of infrastructure development and investment. Also, a comprehensive plan should be established to ensure that the affected minorities' returns are supported via infrastructure needs assessment and the securing of budget line items. In addition, it is recommended that Iraq implements communitybased reconciliation mechanisms toward reintegrating groups that remained with those that fled areas such as the Nineveh Plains. Applicable property documentation should also be collected to provide restitution and reparations to those who lost livelihoods and homes in Diyala, Sahal al-Din, Kirkuk, and Ninewa governorates.

To ensure that the mandate of the High Commission for Human Rights is implemented, the federal government should offer relevant resource support, upon which human rights violations targeting vulnerable groups such as minorities might be monitored and reported timely. In Iraqi police and security forces, the representation of minorities needs to be strengthened, a process that needs to be complemented by the development of a special police unit whose role will be to handle sectarian, religious, or ethnic bias, as well as hate crimes. 
For Iraqi refugees, there is a need for the international community to ensure that entry is allowed, especially because of the fleeing from persecution. Also, refoulement needs to be barred to ensure that the refugees, whose freedom and lives remain at risk, do not return to Iraq without proper planning. Furthermore, policies such as background checks and asylum criteria ought to be adjusted in a way that would ensure that inconsistent identity documentation is recognized relative to the magnitude of the conflict, a situation that would see the community characterized as one that would have committed to displaced minorities' resettlement and longer-term protection.

For the NGOs based in Iraq, the international community needs to provide assistance to support the initiatives' humanitarian operations. Also, financial support needs to be provided urgently to organizations such as international NGOs, Red Crescent Movement or Red Cross, and the UN system, upon which the response led by the Iraqi government might run smoothly. Similarly, it is recommended that in the wake of extreme winter conditions, emergency relief is provided immediately, including essentials such as medical supplies, tents, water, and food. However, this intervention needs to be organized in such a way that the actors collaborate with KRI and other humanitarian groups.

To avert future abuse, it is recommended that concrete steps are developed and implemented to curb material support and financial transfer to armed groups. Additionally, the international community should ensure that while providing military assistance, it liaises and shares intelligence with minority organizations, especially regarding the communities' security. Furthermore, it is critical that the international community abides by international human rights law and international law while taking action against armed groups in Iraq, especially while supporting the Iraqi government. For KRI, priority needs to involve establishing secure areas, a step that might pave the way for the affected groups' safe return to their original lands and homes. Also, the Kurdish Constitution's Articles 36, 35, 14, and 5 ought to be extended to ensure that Shabak and Yazidi are recognized as different identities, upon which future documentation might be easier, especially while responding to similar emergencies. Also, this step is poised to ensure that any historical injustices that these minorities might have faced and constituted to the armed groups' violations of their human rights are alleviated.

For the case of KRI and its response to the humanitarian crisis in Iraq, priority needs to involve children, as well as women and young girls who have been victims of sexual abuse. Similarly, the discriminatory way in which essential services have been reported to be provided needs to cease and ensure that the involved state officials are apprehended, and justice served accordingly - based on the draft Kurdish Constitution's Article 19. For the displaced minorities' winterised and adequate living arrangements, the KRI need to collaborate with donor governments and international organizations, upon which the quest to provide the needed humanitarian assistance might be realized. 


\section{Conclusion:}

In conclusion, the period after June 2014 has seen forces from the Islamic State (ISIS), an armed group, spread quickly across Iraq. This process has led to massive displacements in which the armed group has uprooted over two million people. Indeed, the primary targets of ISIS have been religious and ethnic minorities. Some of these groups include Yazidis, Turkmen, Shabak, Kaka'i, and Christians. Also, ISIS has abducted or injured many people, with thousands also killed. Examples of adverse actions that the armed group has committed include severe human rights abuses such as the looting of property, the abduction of children, the destruction of places of worship, sexual enslavement, rape, forced conversion, and summary executions. Whereas the period before the insurgency group's entry still witnessed minorities exist as a vulnerable group, the violence led by ISIS has threatened to eliminate them permanently from regions such as the Nineveh Plains, have lived in these areas for several centuries. Currently, informal settlements, abandoned buildings, and camps in which the displaced persons live reflect deteriorating humanitarian conditions. With international agencies experiencing limited resources and also the government failing to offer an effective response, most of the IDPs do not have enough shelter, health care, water, food, and other essential items. Notably, most vulnerable groups include children and women. At a time when the majority are contemplating emigration out of Iraq, their survival in the immediate and far future rests upon collaboration among four groups that include the international community, the Iraqi government, Kurdish authorities, and minorities themselves. To realize effective self-governance and a smooth transition for Iraqi minorities, especially after the liberation of Mosul, some of the specific areas that need to be addressed include the asylum dilemma, reconciliation and restoration, preventing future abuses, legislation, and humanitarian issues. In the future, it is recommended that research studies examine some of the ways in which selfgovernance in the Nineveh Plains, if achieved, might shape the population demographics of minorities.

\section{Author contribution}

The first author led the research, preparation and the writing the manuscript; while the second and third authors has contributed in reviewing the study, as they are supervisor and cosupervisors of the author's $\mathrm{PhD}$ in International Relations Multidisciplinary Doctoral School Corvinus University of Budapest - Security subprogram. 


\section{References:}

Ali, M. H. (2017). Religious Minorities in Early Republican Iraq (1958-1968): Between Granting Rights and Discrimination, a Sociopolitical and Historical Study. Bamberg University, Germany

Ali, M. H. (2019). Aspirations for Ethnonationalist Identities among Religious Minorities in Iraq: The Case of Yazidi Identity in the Period of Kurdish and Arab Nationalism, 1963-2003. Nationalities Papers, 47(6), 953-967

Ali, M. H. (2019). The Controversy of the Religious Minorities Identities in Iraq: The Crystallization of the Yazidi Identity after 2003. British Journal of Middle Eastern Studies, 1

Cetorelli, V. and Ashraph, S. (2019). A demographic documentation of ISIS's attack on the Yazidi village of Kocho LSE Middle East Centre reports. LSE Middle East Centre, London, UK

Crone, J. (June 5, 2015). "Christian family in ancient Iraqi city of Nineveh prepare to defend 2,700 year-old tomb of Jewish prophet, as ISIS armies advance to just 10 miles away." mailOnline. Retrieved on January 14, 2019, from https://www.dailymail.co.uk/news/article-3112585/Christian-family-ancient-Iraqi-city-Nineveh-preparedefend-2-700-year-old-tomb-Jewish-prophet-ISIS-armies-advance-just-10-miles-away.html

Dewachi, O. (2017). Ungovernable Life: Mandatory Medicine and Statecraft in Iraq. Stanford, CA: Stanford University Press

Dietrich, L. and Carter, S. E. (2017). Gender and Conflict Analysis in ISIS Affected Communities in Iraq. UN Women

Donabed, S. G. (2015). Reforging a Forgotten History: Iraq and the Assyrians in the Twentieth Century. Edinburgh: Edinburgh University

Gardner, J. (2016). No Way Home: Iraq's minorities on the verge of disappearance. IILHR, MRG, NPWJ, UNPO

Hanish, S. (2015). The Islamic State Effect on Minorities in Iraq. Review of Arts and Humanities, 4(1), 7-11

Helfont, S. (2018). Compulsion in Religion: Saddam Hussein, Islam, and the Roots of Insurgencies in Iraq. Oxford University Press

Ibrahim, R. (October 28, 2018).” The Annihilation of Iraq's Christian Minority.” Gatestone Institute International Policy Council. Retrieved on January 14, 2019 from https://www.gatestoneinstitute.org/13193/iraq-christiansannihilation 
Johnston, P. B., Alami, M. and Clarke, C. P. et al. (2019). Return and Expand? The Finances and Prospects of the Islamic State after the Caliphate. RAND Corporation

Kaya, Z. (2019). Iraq's Yazidis and ISIS: the causes and consequences of sexual violence in conflict. LSE Middle East Centre, London, UK

Millare, M. A. (2019). Defeating ISIS IN Iraq: A Race against Time. NCO Journal, 1-6

Mosul Study Group (2017). Mosul study group: What the Battle for Mosul teaches the force. Department of the Army

O’Driscoll, D. (2017). Autonomy Impaired: Centralisation, Authoritarianism and the Failing Iraqi State. Ethnopolitics $17(4), 315-322$.

Oehring, O. (2017). Christians and Yazidis in Iraq: Current Situation and Prospects. Konrad-Adenauer-Stiftung

Robinson, E., Egel, D. and Johnston, P. B. et al. (2017). Islamic State comes to town: The economic impact of Islamic State governance in Iraq and Syria. Rand

Rubaii, K. J. (2019). Tripartheid: How Sectarianism Became Internal to Being in Anbar, Iraq. American Anthropological Association, 42(1), 125-141

Salloum, S. (2017). At Crossroads: Iraqi Minorities after ISIS. Baghdad: Heartland Alliance International

Shea, N. (2016). The ISIS Genocide of Middle Eastern Christian Minorities and Its Jizya Propaganda Ploy. Center for Religious Freedom, Hudson Institute

UNHCR (2019). International Protection Considerations with Regard to People Fleeing the Republic of Iraq. Author

Wainscot, A. (2019). Engaging the Post-ISIS Iraqi Religious Landscape for Peace and Reconciliation. United States Institute of Peace

Zaman, A. (2016). From Tribe to Nation Final: Iraqi Kurdistan on the Cusp of Statehood. Wilson Center Middle East Program Occasional Paper Series.

Kurdistan24, n.d. Official: Baghdad-appointed Kirkuk governor imposes Arabization policy in 500 Kurdish villages [WWW Document]. Kurdistan24.

URL https://www.kurdistan24.net/en/news/5e1bcca1-5f9a-4da4-8168-b7e108fbe2da (accessed 6.23.20). 